\title{
Preschool Children's Early Mathematics Achievement Based on Gender and Ethnicity
}

\author{
Rohaty Mohd Majzub ${ }^{1}$ \\ ${ }^{1}$ Faculty of Education, Universiti Kebangsaan Malaysia, Selangor, Malaysia \\ Correspondence: Rohaty Mohd Majzub, Faculty of Education, Universiti Kebangsaan Malaysia, 43600 UKM \\ Bangi, Selangor, Malaysia. Tel: 60-3-8921-6261. E-mail: rohatymajzub@yahoo.com
}

$\begin{aligned} & \text { Received: September 20, } 2012 \quad \text { Accepted: November 7, } 2012 \quad \text { Online Published: November } 30,2012 \\ & \text { doi:10.5539/ass.v8n16p24 }\end{aligned} \quad$ URL: http://dx.doi.org/10.5539/ass.v8n16p24

\begin{abstract}
Achievements in Mathematics are said to be influenced by several factors including gender and ethnicity. The purpose of this study was to determine the overall early mathematics achievements of preschool children and whether there were significant differences in those achievements based on gender and ethnicity. The instrument used in this research was the Early Mathematics Achievement Test(EMAT) which was adapted from two preschool mathematics modules and the National Standard Preschool Curriculum Malaysia. The research sample consisted of 138 preschool children from six Ministry of Education preschools in Malaysia stratified according to gender and ethnicity. The data was analyzed descriptively and inferentially. The t-test and ANOVA were used to test gender and ethnic differences in the mathematics achievements. The findings showed that the level of preschool children's early mathematics achievements was above average. There were no significant differences in their mathematics achievement based on gender. However, there were significant differences in their early mathematics achievement based on ethnicity. We therefore argue that ethnicity is a factor that can probably affect preschool children's early mathematics achievement. The role of gender in mathematics achievement needs to be further examined in future studies to clarify the inconclusive findings of past research.
\end{abstract}

Keywords: mathematics achievement, gender, ethnicity

\section{Introduction}

The sixth challenge of Vision 2020in Malaysia is the development of a scientific and progressive society, which integrates science and technology in teaching and learning(The Way Forward 1991) Undeniably, achievement in the field of science and mathematics is a very important national agenda which affects all levels of education starting from preschool till the tertiary level. In 2003, the implementation of teaching science and mathematics in the English language was carried out with focus on students in Standard One and Forms One and Six. To this end, basic mathematics proficiency needs to be strengthened since the preschool level is the foundation for future performance. If early mathematics skills can be enhanced, children will be better prepared to face the challenges of learning mathematics during later school years and subsequently at higher institutions of learning. At present, preschool education is an important phase in Malaysia's education system with billions of ringgit invested in the private and public sectors to ensure quality and equity in the delivery of preschool services ( LAPPPM 2013-2025)

The development of mathematics is always parallel with the development of human civilization itself (Sabri et al. 2006). According to Dorfler (2003), mathematics is highly relevant to the demands of daily living. Mathematics is considered a form of art and beauty as well as an effective communication tool. In this era of globalization, the world is dominated by science and technology with attention on strong mastery of mathematics. The National Standard Preschool Curriculum Malaysia (2012) devotes much attention to early mathematics, particularly elements such as classification, seriation, one-to-one correspondence and computation.

The poor performance of children in mathematics is highly obvious as the statistics show that more than 100,000 primary school students in Malaysia are currently unable to master the skills of reading, writing and mathematics (Pelan Pendidikan 2000-2013). Lyon et al. (2001) found that students with poor academic achievements in their foundation years will struggle to acquire higher mathematical skills in later years.

However, this failure can be overcome if children are able to associate mathematics with their daily lives. 
According to Baroody (2000), preschool children need to develop a variety of relevant mathematical concepts. They need to learn to give reasons and communicate using mathematics. They need to be exposed to early experiences, situations and problems associated with numbers. They need to develop mathematical ideas which are linked to the abstract.

What factors affect mathematical achievements? Studies in mathematical achievements are relatively new and scarce at the preschool level in Malaysia since previous studies generally focused on the mathematical performance of older students. Gender has always been considered an important determining factor. Boys are said to be more spatially oriented than girls. Boehlaert et al. (1995) found that female students have poor motivation when it comes to mathematics skills. Similarly, Carr et al. (1999) stated that female students achieve less success in mathematics test compared to male students.

Mokhtar (2000) examined the relationship between mathematical problem-solving achievements and related factors among high school students. The sample consisted of 188 students from Form One. The results showed that male students scored higher in mathematics. However, Zurhiati (1998) found no significant differences in mathematical achievements, attitudes towards learning mathematics and interest in mathematics between male and female students.

Ethnicity is also a factor which influences mathematical achievements. Malaysia is a multi-ethnic society comprising of Malays, Chinese and Indians. Research has shown that Chinese students excel more at mathematics compared to the other ethnic groups because mathematics is taught systematically and rigidly in Chinese preschools. Such high accountability has been placed on mathematics because the Chinese are generally more immersed in the world of business. The Malaysian Vision 2020, and the Education Blue Print of (2012-2025) seeks to ensure equity and educational opportunities for students' achievements regardless of ethnicity or gender.

Zahidi (1997) carried out a study in five secondary schools in Kinta district, Perak on a random sample of 370 secondary school students. The study found that a significant relationship existed between gender, ethnicity, education and income of parents, school facilities, teachers and mathematical achievements. Another study by Hashim (1997) in the district of Seberang Jaya aimed to discover the factors connected to the achievements of Form 4 science stream students in Additional Mathematics. There were 269 students selected as a sample from a population of 856 students. The findings showed that there were significant differences in mean scores between Malay students and Chinese students. The results also demonstrated that Chinese and Indian students performed better in advanced mathematics compared to Malay students. Mahmud (1991) conducted research to find out whether there were differences in students' achievements and perception of mathematics teaching activities based on location, ethnicity and gender. The results showed that non-Malay students' performance in mathematics was much better than Malay students.

Hafiza's (2005) study on preschoolers' vocabulary achievement found that there were significant differences in English vocabulary achievements based on ethnicity. Indian children demonstrated the highest level of English vocabulary achievements, followed by the Chinese and lastly the Malays. Likewise, Phang (2004) found that ethnicity played a role in distinguishing the ability to read English among preschool children. Thus, the objectives of this study were (a) to identify the level of preschool children's early mathematics achievement; (b) to identify the differences in preschool children's early mathematics achievement based on gender; and (c) to identify the differences in preschool children's early mathematics achievement based on ethnicity.

The Research Questions are as follows:

1) What is the level of preschool children's early mathematics achievement?

2) Are there any significant differences in children's early mathematics achievement based on gender?

3) Are there any significant differences in children's early mathematics achievement based on ethnicity?

The Research Hypotheses are as follows:

1) There are no significant differences in children's early mathematics achievement based on gender.

2) There are no significant differences in children's early mathematics achievement based on ethnicity.

\section{Research Design}

This study is a quantitative study assessing the early mathematics achievement of Malaysian preschool children.

(a) Research Methodology

The study sample comprised of 138 six years-old preschool children who were obtained through stratified 
random sampling. Six preschools organized by the Ministry of Education Malaysia were randomly selected from urban residential areas in Selangor Malaysia. The parents of the preschool children are from the high to middle income group. The sample was stratified according to gender and ethnicity. The preschool children in the sample had attended preschool for nearly 2 years from the ages of 4 to 6 . The Ministry of Education preschools focus on the total and holistic development of young children with strong emphasis on early mathematics as an important thrust of the curriculum.

\subsection{The Instrument}

The instrument used in the study was the Early Mathematics Achievement Test (EMAT). EMAT was developed and adapted from the Malaysian National Standard Preschool Curriculum Guide and preschool Mathematics Modules developed by Saayah \& Asiah (2004) and Kamisah \& Marlinda (2006). EMAT comprises of two sections, namely Section A which concerns the background of the respondents and (b) Section B which contains the battery of subtests along with the marks specifically allocated to each subtest. These subtests include (a) Classification(21 marks) (b) Seriation (5marks) (c) One-to-One Correspondence(9 marks) (d) Concept of numbers 1-10 (18 marks) (e) Concept of Number 10-20 (22 marks)(f) Concept of Number 20-30 (9 marks) (g)Concept of Number 30-40 (9 marks)(h)Concept of Number 40-50 (9 marks)(i) Simple Addition (39 marks) (j) Simple Subtraction( 39 marks) and (g) Concept of Quantity(9 marks). The content validity of EMAT was established through expert judgment. The experts were five preschool teacher trainers from teacher training institutions as well as five experienced preschool supervisors. Inter-rater agreement was initially $95 \%$ but was reconciled to $100 \%$ after the disagreements were discussed. The reliability of EMAT was established through Test Retest reliability among twenty-five preschool children who were not part of the sample. The reliability of the test items was achieved with Alpha Cronbach values ranging between 0.75 and 0.90 . Early mathematics achievement was calculated based on the scores obtained from a minimum score of 68 marks and a maximum score of 189 marks.

\subsection{Procedures}

The EMAT constitutes a paper and pencil test which was administered to approximately 189 preschool children with the help of preschool teachers and researchers from the six preschool centers involved. Each preschool center had approximately between 20 to 25 preschool children. All of the preschool centers were notified and the teachers oriented to the testing procedures and requirements. The EMAT was administered to the group of preschool children specified in the classroom at each preschool center. The tests took two hours to complete with a break of an hour in between the tests. Each preschool center was assigned one day for the test. Each correct answer given by the child received a score of 1 and a score of 0 for an incorrect response. The total score for EMAT was 189.

\subsection{Data Analysis}

The data obtained from EMAT administered was analyzed using both descriptive and inferential statistics. The descriptive statistics involved frequencies, means and percentages while the inferential statistics involved the use of a T-test and ANOVA.

\section{Results}

Table 1 describes the sample involved in the study. As evident from the table, there was a balance of 70 boys (51\%) and 68 girls $(49 \%)$ with a total of 138 preschool children. There was also a balance in the ethnic composition between Malays, (49) Chinese (44) and Indians (45) totaling 138 preschool children.

Table 1 . Gender and ethnicity of children

\begin{tabular}{cccc}
\hline Variable & Group & Number of Sample (n) & Percentage (\%) \\
\hline Gender & Boy & 70 & 51 \\
& Girl & 68 & 49 \\
& Total & 138 & 100 \\
Ethnicity & Malay & 49 & 35 \\
& Chinese & 44 & 32 \\
& India & 45 & 33 \\
& Total & 138 & 100 \\
\hline
\end{tabular}




\subsection{Overall Early Mathematics Achievement Scores}

Table 2 describes the early mathematics achievement of the preschool children involved in this study. There are two levels of achievement, namely average and above average. The average achievements mean score ranged from 68 to 153.11 while the above average mean score ranged from 153.11 to 189). The mean score of respondents was 153.11 with a standard deviation of 32.47. This indicates that although the average score was not at the maximum (189), the children still obtained the minimum cutting point of above average mathematics scores.

Table 2. Descriptive statistic of students' early mathematic achievement

\begin{tabular}{ccccc}
\hline Variable & $\mathrm{N}$ & Mean & Standard division & Range \\
\hline Early Mathematic Achievement & 138 & 153.11 & 32.47 & 121.0 \\
\hline
\end{tabular}

\section{Inferential Analysis}

\subsection{Early Mathematics Achievement Scores According to Gender}

Ho $1=$ There were no significant mean differences in the early mathematics achievement scores between boys and girls.

Table 3 shows the results of the $t$-test indicating $(t=0.841, p=0.402$.) $(p>0.05)$. Thus, the null hypothesis is accepted. This means that there were no significant differences in early mathematics achievement between boys $($ mean $=150.81)$ and girls (mean=155.47).

Table 3. Early mathematics achievement scores between boys and girls

\begin{tabular}{cccccc}
\hline Gender & N & Mean & SD. & t-value & Sig. Level \\
\hline Boys & 70 & 150.81 & 32.47 & 0.841 & 0.402 \\
Girl & 68 & 155.47 & 32.55 & &
\end{tabular}

\subsection{Early Mathematics Achievement Scores According to Ethnicity}

$\mathrm{H}_{\mathrm{o}} 2$ = There were no significant mean differences in early mathematics achievement scores between Malay, Chinese and Indian preschool children

Table 4 shows the results of ANOVA denoting that there were significant differences for early mathematics achievement scores based on ethnicity $(\mathrm{F}=8.531)(\mathrm{p}=.000)$.

Table 4. ANOVA of early mathematics achievement based on ethnicity

\begin{tabular}{cccccc}
\hline Variance & df. & Total Square & Mean Square & F & Significant \\
\hline Among Groups & 2 & 16211.543 & 8105.772 & & \\
In Group & 135 & 128265.830 & 950.117 & 8.531 & .000 \\
Total & 137 & 144477.37 & & & \\
\hline
\end{tabular}

The Post Hoc Turkey Test was conducted to determine the significance of the differences between the three ethnic groups. Table 5 shows that Chinese preschool children have the highest mean difference (166.7500) whereas Indian preschool children have the lowest. In addition, the mean of Chinese preschool children is higher than the means of Indian (139.7556) and Malay preschoolers (153.1224) with a difference of 26.9944*. This indicates that Chinese preschool children have the highest early mathematics achievement scores.

Table 5. Results of post hoc turkey test

\begin{tabular}{lcccccc}
\hline & Ethnicity & Mean(I) & $\begin{array}{c}\text { Ethnic Groups } \\
(\mathrm{J})\end{array}$ & $\begin{array}{c}\text { Mean Differences } \\
(\mathrm{I}-\mathrm{J})\end{array}$ & $\begin{array}{c}\text { Standard } \\
\text { Deviation }\end{array}$ & Significance \\
\hline EMAT & Malays & \multirow{2}{*}{153.1224} & Chinese & -13.6276 & 6.40186 & .088 \\
Scores & & & Indian & 13.3669 & 6.36426 & .094 \\
& \multirow{2}{*}{ Chinese } & \multirow{2}{*}{166.7500} & Malay & 13.6276 & 6.40185 & .088 \\
& & & Indian & $26.9944^{*}$ & 6.53508 & .000 \\
& \multirow{2}{*}{ Indian } & \multirow{2}{*}{139.7556} & Malay & -13.3669 & 6.36426 & .094 \\
& & & Chinese & $-26.9944^{*}$ & 6.53508 & .000 \\
\hline
\end{tabular}




\section{Discussion}

\subsection{Overall Early Mathematics Achievement of Preschool Children}

Overall, the level of early mathematics achievement of the preschool children was above average. Plausible factors may be attributed to the early mathematics training given to the preschool teachers as well as the curiosity of the children (Rohani et al. 2004). Children are generally able to identify and understand the concept of numbers easily during their experimental early years. Rohani et al. (2004) stated that every normal child is able to understand mathematical concepts well if given appropriate curricular activities and methods of engaging their interests. Even in their daily lives, mathematical concepts appear to exist and are relevant. The findings of this study are consistent with research carried by Norma (2005), who studied 836 children and found that the majority of children were well acquainted with mathematical concepts.

In conclusion, the level of early mathematics achievement of preschool children is above average. However, the large range of differences in marks shows the existence of diverse children within the sample. These differences may be due to other factors that require further research such as IQ, interests, attitudes, motivation and language.

\subsection{Differences in Early Mathematics Achievement According to Gender}

The results showed that there were no significant differences in early mathematics achievement between male and female preschool children $(\mathrm{t}=0.841, \mathrm{p}=0.402)$. These findings support the findings of earlier studies by Rahim (1997) and Zurhiati (1998). The gender factor is thus not the determining factor in a child's mathematics achievement. This may be due to the influence of location as the sample students in this study live in middle income urban areas where parents are keenly aware of the importance of education and achievement for their children. In addition, there are other factors such as the common preschool curriculum, teaching techniques, intellectually stimulating environments available in affluent urban areas and similar values and priorities that parents provide for their children regardless of gender.

\subsection{Differences in Early Mathematic Achievement According to Ethnicity}

The analysis showed that there were significant differences in early mathematics achievement according to ethnicity. Malay preschool children obtained (mean=153.1224), Chinese (mean=166.7500) and Indians (mean=139.7556). This finding supports the study of Zahidi (1997), Hashim (1997) and Mahmud (1991). This demonstrates that non-Malays performed better than Malays. One probable reason for this is the cultural orientation and importance attached by Chinese parents to mathematics. The Chinese tend to inculcate mathematical values in the upbringing of their children as seen in family businesses which are passed down from generation to generation. On the other hand, Malay parents are more inclined towards the arts, culture and aesthetics.

\section{Conclusion and Implications}

The findings of the study indicate that there were no differences in early mathematics achievement between boys and girls at the preschool stage. However, educators should be wary of the fact that several factors may exist to affect the achievement of boys and girls at the later stages of development such as at the tertiary stage. Boys may develop at a slower pace compared to girls at the initial stage, but achieve higher scores later on to pave their way to careers such as engineering and the other hard sciences. In contrast, gender differences in learning may not exist at the more flexible preschool stage; they become more marked upon entering the elementary, secondary and tertiary levels. Given the higher academic achievement of girls compared to boys and the lower numbers of boys entering the universities today, educators are still in search of answers on effective approaches to teach boys, even in the field of mathematics which are traditionally a male domain. Further studies need to be conducted to ascertain the socio psychological climate in the preschool environment that encourages similar achievement in mathematics between boys and girls, and whether such an environment can be sustained at the higher levels of learning.

Ethnicity is an important factor to be reckoned with in multi-racial Malaysia. The Malaysian government's 1Malaysia aspiration propagated by the present Prime Minister, Najib Razak, stresses on equity and equality in learning and achievement. Educators can learn from the Chinese in terms of how they inculcate mathematical concepts and values to children formally and informally. An ethnographical and phenomenological study on Chinese values relating to mathematics is thus warranted. It is hoped that based on the grounded theory model, relevant child rearing practices aimed at motivating interest in mathematics can be derived and shared by other ethnic groups.

Although the overall results of the study show above average achievement in early mathematics for preschool children, educators are advised not to be complacent. At the preschool stage, concepts are taught at the concrete 
operation level. Total development of the child such as physical, emotional, social and intellectual domains of development is not usually emphasized in the more rigid secondary school curriculum. Thus, the ambience of the preschool setting, especially in urban preschool centers which emphasize playing and the joy of learning may be absent at the elementary and secondary level. Due to the limitations of this study, it is recommended that further studies be initiated to test these findings for a more viable generalization.

\section{References}

Abdullah, R., Menon, N., \& Ahmad, M. S. (2004). Panduan kurikulum prasekolah. Pahang: PTS Publicaitons \& Distributor Sdn Bhd.

Abu, S., \& Ismail, A. (2004). Happy Child Maths. Batu Caves: Zafani Teguh Sdn Bhd.

Ahmad, S., Zainal, Z. T., \& Omar, A. (2006). Isu-isu dalam pendidikan matematik. Kuala Lumpur: Utusan Publications \& Distributor Sdn. Bhd.

Baroody, A. J. (2000). Does mathematics instruction for 3 to 5 years old really make sense? The Journal of NAEYC, 55, 61-67.

Boelaerts, M., Seegers, G., \& Vermeer, H. (1995). Solving math problems: Where and why does the solution process go astray? Education Studies in Mathematics, 28, 241-262. http://dx.doi.org/10.1007/BF01274175

Buang, K., \& Yusof, M. (2006). Mathematics 1 \& 2. Kluang: Penerbitan PHD (M) Sdn. Bhd.

Carr, M., Jessup, D. L., \& Fuller, D. (1999). Gender differences in first-grade mathematics strategy use: Parents and teacher contributions. Journal for Research in Mathematics Education, 30, 20-27. http://dx.doi.org/10.2307/749628

Ching, P. K. (2004). Kesediaan membaca Bahasa Inggeris di Kalangan Kanak-kanak Prasekolah. Unpublished Master's thesis, Universiti Kebangsaan Malaysia.

Dorfler, W. (2003). Mathematics and mathematics education: Content and people, relation and differences. Educational Studies in Mathematic, 54, 147-170. http://dx.doi.org/10.1023/B:EDUC.0000006118.25919.07

Harun, H. (1997). Faktor-faktor yang mempengaruhi pencapaian pelajar dalam Matematik Tambahan pelajar tingkatan empat di Seberang Perai. Unpublished Master's thesis, Universiti Utara Malaysia

Ibrahim, N. (2005). Program bimbingan kanak-kanak prasekolah dalam kemahiran membaca dan matematik. Unpublished Master's thesis, Universiti Kebangsaan Malaysia.

Ishak, M. (2000). Hubungan pencapaian penyelesaian masalah matematik dengan gaya belajar dan faktor-faktor perkaitan di kalangan pelajar-pelajar sekolah menengah rendah. Unpublished Master's thesis, Universiti Putra Malaysia.

LAPPPM 2013-2025 (Laporan Awal Pelan Pembangunan Pendidikan Malaysia). Ministry of Education, Malaysia.

Lyon, G. R., Fletcher, J., Shaywitz, S., Shaywitzm B., Torgeson, J., \& Wood, F. (2001). Rethinking learning disabilities. In. Finn, C., Rotterham, A., \& Hokanson, C. (Eds.), Rethinking special education for a new century. Washington D.C.: Fordham Foundation.

Mohd Nor, R. H. (1997). Kemahiran penyelasaian masalah matematik di kalangan pelajar menengah rendah. Unpublished Master's thesis, Universiti Kebangsaan Malaysia.

National Standard Preschool Curriculum Malaysia. (2012). Ministry of Education, Malaysia.

Pelan Pembangunan Pendidikan Malaysia (2000-2013) Kementerian Pendidikan Malaysia.

Saad, Z. (1998). Faktor psikologi yang berkait dengan pencapaian dalam matematik di kalangan sekolah pinggir bandar. Unpublished Master's thesis, Universiti Putra Malaysia.

Sulaiman, H. (2005). Pencapaian kosa kata Bahasa Inggeris Kanak-kanak Prasekolah. Unpublished Master's thesis, Universiti Kebangsaan Malaysia.

The Way Forward: Vision 2020. (1991). Prime Minister's Department, Malaysia.

Yahya, M. (1991). Pencapaian dan persepsi pelajar-pelajar tingkatan satu terhadap aktiviti pengajaran matematik. Unpublished Master's thesis, Universiti Kebangsaan Malaysia.

Yusof, Z. (1997). Beberapa pembolehubah tentang pencapaian matematik (PMR) pelajar-pelajar tingkatan empat, daerah Kinta Perak. Unpublished Master's thesis, Universiti Putra Malaysia. 